\title{
Impact of Gender in Adopting and Using ICTs in Spain
}

\author{
Ana Gargallo-Castel, Luisa Esteban-Salvador, Javier Pérez-Sanz'
}

\begin{abstract}
The main objective of this paper is to analyse the impact of gender in adopting and using new information and communication technologies (ICTs) in Spain. It is widely accepted that men tend to be the first to use new technologies and to gain significant benefits from doing so, both at home and work. However, further research on gender and new technologies, such as ICTs, is still needed in order to better understand differences between men and women. On the one hand we show that percentage of ICTs users is higher among men. On the other hand, our results confirm that women also present lower frequency of ICTs use. We examine how the differences in adoption and use of ICTs are moderated by cultural and socioeconomic aspects. Differences appear mainly in the lower levels of education and in the rural area. Therefore, it highlights the necessity of taking into account those aspects to remove the gender digital divide totally. We also underline the importance of changes in gender roles and the increase of the participation of women in the Spanish labour force.
\end{abstract}

Key words: gender; skills; education, work; information and communication technologies; rural area; Spain; digital divide.

\section{Resumen}

El objetivo principal de este trabajo es analizar el impacto del género en la adopción y utilización de las tecnologías de la información y la comunicación (TIC) en España. Está generalmente aceptado que los hombres tienden a ser los primeros en usar las nuevas tecnologías y en obtener ventajas significativas de ello, tanto en el hogar como en el trabajo. Sin embargo, sigue siendo necesarios nuevos estudios sobre la relación entre el género y las nuevas tecnologías, como las TIC, para entender mejor las diferencias entre hombres y mujeres. Por un lado, se observa que el porcentaje de usuarios de las TIC es más alto entre los hombres. Por otro lado, nuestros resultados confirman que las mujeres también presentan menor frecuencia de uso de las TIC. Se muestra también como las diferencias de adopción y uso de las TIC son moderadas por aspectos culturales y socioeconómicos. Las diferencias aparecen principalmente en los niveles inferiores de educación y en las áreas rurales. En definitiva, destaca la necesidad de tener en cuenta estos aspectos para eliminar totalmente la brecha digital debida al género. También destaca la importancia de los cambios en los roles en función del género y el aumento de la participación de la mujer en el mercado de trabajo en España.

Palabras clave: género; habilidades; educación, trabajo; tecnologías de la información y la comunicación; área rural; España; brecha digital.

\footnotetext{
' Department of Business Administration. University of Zaragoza, C/ Ciudad Escolar, s/n. 44003 Teruel, Spain. Tel.: 00349786 I8I0I. Fax: 00349786181 03. Email: gargallo@unizar.es (corresponding author), luisaes@unizar.es, fjperez@unizar.es
} 


\section{Introduction}

Along the past 20th century there have been a huge range of changes. One of the most important has been the transformation of the social role of women. Historically, women have been involved in jobs without remuneration, typically working in domestic labour. But in the last years their progressive incorporation into the labour market has supposed a point of inflexion. During the last decades, the labour force participation rate for women has been raised dramatically. This massive incorporation of women to the labour market has also stimulated their possibilities of access to the new technologies. However, a gender digital divide still exist, not only in the developing countries, but also in some developed countries, such as Spain. In most cases, in contrast to the general patterns of women participation increase, the gender distribution of ICTspecialist is an outlier.

\section{Women and Technology}

Nowadays, Information and Communication Technologies (ICTs) are increasingly recognized as a powerful tool for facilitating sustainable human development (UNDPUNIFEM, 2004). Remarkable changes brought by ICTs have created new economic and social opportunities the world over. However, several studies highlight gender inequalities. Evidence shows that men tend to be the first to use new technologies and to use them more, whereas women are underrepresented both as users of computers and employees in the ICTs business. This reflects the socalled a gender digital divide.

"Digital divide" refers to the gap between individuals, households, businesses and geographic areas at different socio-economic levels with regard to both their opportunities to access information and communication technologies (ICT) and to their use for a wide variety of activities. More specifically, the gender digital divide indicates the under-representation of women in the ICTsrelated fields (Bucy, 2000; Castaño, 2005; Fink and Kenny, 2003; Korupp and Szydlik, 2005; among others). Academic literature has commonly distinguished between first and second digital divide.

First Digital Divide: It refers to the gap in the access to new technologies. For example, according to the e-Living survey (Raban, 2004), the gender gap in the PC use is quite high in some countries, and there is even larger gap in Internet use (up to 18\%). The largest gaps in the PC and Internet use are showed in Italy and Germany.

\begin{tabular}{|l|c|c|c|c|c|c|}
\hline & \multicolumn{3}{|c|}{ PC use } & \multicolumn{3}{c|}{ Internet use } \\
\hline & Female & Male & Gap & Female & Male & Gap \\
\hline UK & $63 \%$ & $70 \%$ & $-7 \%$ & $55 \%$ & $61 \%$ & $-6 \%$ \\
\hline Italy & $56 \%$ & $71 \%$ & $-15 \%$ & $42 \%$ & $59 \%$ & $-17 \%$ \\
\hline Germany & $61 \%$ & $75 \%$ & $-14 \%$ & $44 \%$ & $62 \%$ & $-18 \%$ \\
\hline Norway & $74 \%$ & $85 \%$ & $-11 \%$ & $64 \%$ & $78 \%$ & $-14 \%$ \\
\hline Bulgaria & $15 \%$ & $13 \%$ & $2 \%$ & $8 \%$ & $9 \%$ & $-1 \%$ \\
\hline Israel & $63 \%$ & $65 \%$ & $-2 \%$ & $46 \%$ & $52 \%$ & $-6 \%$ \\
\hline
\end{tabular}

Table I. ICTs use. Source: e-Living survey (2004)

Second Digital Divide: It includes the gap in the quantity and intensity of new technologies use. Distinguishing between light and heavy users, results of e-Living survey (Raban, 2004) show up that more than $60 \%$ of women are light users, while they represent only $40 \%$ of the heavy users group. As Dholakia and Kshetri (2002) discuss, men and women seem to be specialized in different tasks and have different preferences. According to the Statistical Office of the European Communities (Eurostat), gender gap still persists in 2008. 


\begin{tabular}{|c|c|c|c|c|c|c|c|c|c|}
\hline & Female & Male & Gap & Female & Male & Gap & Female & Male & Gap \\
\hline EU (27 countries) & $41 \%$ & $49 \%$ & $-8 \%$ & $47 \%$ & $56 \%$ & $-9 \%$ & $53 \%$ & $59 \%$ & $-6 \%$ \\
\hline EU ( 25 countries $)$ & $42 \%$ & $51 \%$ & $-9 \%$ & $49 \%$ & $58 \%$ & $-9 \%$ & $54 \%$ & $61 \%$ & $-7 \%$ \\
\hline EU (I5 countries) & $44 \%$ & $53 \%$ & $-9 \%$ & $51 \%$ & $60 \%$ & $-9 \%$ & $56 \%$ & $63 \%$ & $-7 \%$ \\
\hline Euro area & $41 \%$ & $50 \%$ & $-9 \%$ & $48 \%$ & $57 \%$ & $-9 \%$ & $53 \%$ & $60 \%$ & $-7 \%$ \\
\hline Bulgaria & $21 \%$ & $23 \%$ & $-2 \%$ & $28 \%$ & $29 \%$ & $-1 \%$ & $29 \%$ & $31 \%$ & $-2 \%$ \\
\hline Czech Republic & $33 \%$ & $38 \%$ & $-5 \%$ & $39 \%$ & $45 \%$ & $-6 \%$ & $48 \%$ & $54 \%$ & $-6 \%$ \\
\hline Denmark & $76 \%$ & $80 \%$ & $-4 \%$ & $74 \%$ & $79 \%$ & $-5 \%$ & $78 \%$ & $83 \%$ & $-5 \%$ \\
\hline Germany & $54 \%$ & $65 \%$ & $-11 \%$ & $58 \%$ & $70 \%$ & $-12 \%$ & $62 \%$ & $73 \%$ & $-11 \%$ \\
\hline Estonia & $56 \%$ & $57 \%$ & $-1 \%$ & $59 \%$ & $58 \%$ & $1 \%$ & $62 \%$ & $61 \%$ & $1 \%$ \\
\hline Greece & $18 \%$ & $27 \%$ & $-9 \%$ & $23 \%$ & $33 \%$ & $-10 \%$ & $28 \%$ & $38 \%$ & $-10 \%$ \\
\hline Spain & $35 \%$ & $44 \%$ & $-9 \%$ & $40 \%$ & $49 \%$ & $-9 \%$ & $45 \%$ & $54 \%$ & $-9 \%$ \\
\hline France & $37 \%$ & $42 \%$ & $-5 \%$ & $54 \%$ & $61 \%$ & $-7 \%$ & $64 \%$ & $61 \%$ & $3 \%$ \\
\hline Italy & $26 \%$ & $36 \%$ & $-10 \%$ & $28 \%$ & $39 \%$ & $-11 \%$ & $32 \%$ & $43 \%$ & $-11 \%$ \\
\hline Cyprus & $27 \%$ & $32 \%$ & $-5 \%$ & $32 \%$ & $37 \%$ & $-5 \%$ & $32 \%$ & $39 \%$ & $-7 \%$ \\
\hline Latvia & $45 \%$ & $47 \%$ & $-2 \%$ & $51 \%$ & $54 \%$ & $-3 \%$ & $55 \%$ & $59 \%$ & $-4 \%$ \\
\hline Lithuania & $37 \%$ & $38 \%$ & $-1 \%$ & $44 \%$ & $46 \%$ & $-2 \%$ & $49 \%$ & $51 \%$ & $-2 \%$ \\
\hline Luxembourg & $55 \%$ & $76 \%$ & $-21 \%$ & $63 \%$ & $81 \%$ & $-18 \%$ & $66 \%$ & $88 \%$ & $-22 \%$ \\
\hline Netherlands & $71 \%$ & $82 \%$ & $-11 \%$ & $77 \%$ & $85 \%$ & $-8 \%$ & $80 \%$ & $86 \%$ & $-6 \%$ \\
\hline Austria & $49 \%$ & $61 \%$ & $-12 \%$ & $55 \%$ & $67 \%$ & $-12 \%$ & $59 \%$ & $73 \%$ & $-14 \%$ \\
\hline Poland & $32 \%$ & $36 \%$ & $-4 \%$ & $37 \%$ & $41 \%$ & $-4 \%$ & $43 \%$ & $46 \%$ & $-3 \%$ \\
\hline Portugal & $28 \%$ & $35 \%$ & $-7 \%$ & $31 \%$ & $39 \%$ & $-8 \%$ & $34 \%$ & $43 \%$ & $-9 \%$ \\
\hline Romania & $17 \%$ & $20 \%$ & $-3 \%$ & $20 \%$ & $24 \%$ & $-4 \%$ & $25 \%$ & $28 \%$ & $-3 \%$ \\
\hline Slovenia & $42 \%$ & $51 \%$ & $-9 \%$ & $48 \%$ & $50 \%$ & $-2 \%$ & $51 \%$ & $53 \%$ & $-2 \%$ \\
\hline Slovakia & $39 \%$ & $47 \%$ & $-8 \%$ & $49 \%$ & $53 \%$ & $-4 \%$ & $59 \%$ & $65 \%$ & $-6 \%$ \\
\hline Finland & $70 \%$ & $72 \%$ & $-2 \%$ & $73 \%$ & $77 \%$ & $-4 \%$ & $77 \%$ & $80 \%$ & $-3 \%$ \\
\hline Sweden & $76 \%$ & $84 \%$ & $-8 \%$ & $72 \%$ & $79 \%$ & $-7 \%$ & $81 \%$ & $86 \%$ & $-5 \%$ \\
\hline United Kingdom & $51 \%$ & $63 \%$ & $-12 \%$ & $61 \%$ & $70 \%$ & $-9 \%$ & $66 \%$ & $74 \%$ & $-8 \%$ \\
\hline Norway & $73 \%$ & $80 \%$ & $-7 \%$ & $78 \%$ & $83 \%$ & $-5 \%$ & $83 \%$ & $88 \%$ & $-5 \%$ \\
\hline
\end{tabular}

*Data for Macedonia, Malta, Turkey, Iceland, Belgium, Ireland, Hungary are not available

Table 2. Individuals regularly using the Internet, by gender and type. Source: Survey on Information and Communication Technologies in enterprises, Eurostat 
The percentage of women who regularly use the Internet is much lower than that of men, mainly in countries like Luxembourg, Austria, Italy and Germany, where the gap exceeds 10\%. Only France and Estonia present a higher rate of women using the Internet more regularly than men.

There are also differences depending on the type of technology. For example, with respect to the use of email, Dholakia (2004/2005) shows that women report using it more than men. Recently, Kovačić and Vukmirović (2008) have shown that gender only has a significant impact on regular Internet use, while regular PC and mobile phone use were not affected.

\section{Women and ICTs Employment}

During the last years, women have presented low shares of employment than men. Additionally, penetration of ICTs has run parallel to the rate of employment, so the use of new technologies has been higher for men than women. Moreover, among ICTs-using occupations, women tend to have much higher shares of office and secretarial occupations and lower percentage in scientific and professional ones (OECD, 2007).

Data show that women are still underrepresented in many specific professions, for example they comprise just II\% of engineers. As Lenka Simerska of Women's Networking Support Programme -a global organisation supporting women's empowerment through the use of ICTs- highlights,, women are very poorly represented in ICTs employment and "the situation is getting worse because of the low number of girls interested in studying technical subjects at universities". Brynin et al. (2003) question if differences are due to a cultural response to technology, positive for men and negative for women.

However, according to Eurostat, in the EU, $51 \%$ of almost 59 million persons employed in science and technology occupations in 2006 were female, and in Lithuania the percentage reaches $72 \%$ of women (Meri, 2008). Another example is the software and services outsourcing industry in India, where a large number of women have entered this field. So, gender parity is being gradually achieved.

\section{Women and ICTs in Spain}

In this part of the article we review the position of women in the use of a specific ICT such as Internet. We have selected this technology because it is the main exponent of the digital age. We examine its use in Aragón, the region of the north-east of Spain where the University of Zaragoza is located. To achieve our goal in this paper, we have used data obtained by the Aragonese Observatory of the Society of the Information (AOSI, 2008) during the period 2004-2007.

\section{I. Possibility of Access}

Firstly, we are going to analyse differences between men and women according to the place where they access to the Internet. As we can see in the following table, there are not important differences if we distinguish among home access, workplace access and study place access. Although men tend to be more likely technological innovators than women, at the household level we show that the percentage of women using Internet is higher than the percentage of men. As women spend more time at home they have greater opportunity to use ICT there.

\begin{tabular}{|l|l|l|l|}
\hline & Female & Male & Gap \\
\hline Home & $80.73 \%$ & $78.53 \%$ & $2,20 \%$ \\
\hline Workplace & $30.87 \%$ & $34.27 \%$ & $-3,40 \%$ \\
\hline Study place & $84.89 \%$ & $88.54 \%$ & $-3,65 \%$ \\
\hline
\end{tabular}

Table 3. Places of use. Source: AOSI (2008) 
However, when we make a distinction between urban and rural women, we find that home access in rural areas is smaller than it is in urban case. Data show a digital divide of more than 20 percentage points. On the contrary, access in the study place is higher among rural women, and workplace access differences are insignificant. It can be due to a mayor presence of women at the study place in rural areas. However, it probably indicate that the cultural differences between rural and urban life still exist, not at the study or workplace, but at home.

\begin{tabular}{|l|l|l|l|}
\hline & Rural & Urban & Gap \\
\hline Home & $59.69 \%$ & $83.57 \%$ & $-23,88 \%$ \\
\hline Workplace & $33.66 \%$ & $30.50 \%$ & $3,16 \%$ \\
\hline Study place & $91.27 \%$ & $84.03 \%$ & $7,24 \%$ \\
\hline
\end{tabular}

Table 4. Women access to Internet by area. Source: AOSI (2008)

\subsection{Characteristics of Internet Access}

According to our data, gender divide is higher when the "second digital divide" is reviewed. Specifically, differences increase among the group of "frequent users". As we can see on the following table, the gap between men and women in this group almost reaches 15\%. This gap is higher than the Spanish one (45\% female and $54 \%$ male) or the EU (27 countries) one (53\% female and 59\% male) according to Eurostat (2008) although, in general, women tend to use the Internet less frequently than men in all countries (Brynin et al., 2003).

\begin{tabular}{|l|l|l|l|}
\hline & Female & Male & Gap \\
\hline Sometimes & $59.82 \%$ & $69.20 \%$ & $-9,38 \%$ \\
\hline In the last 3 moths & $55.08 \%$ & $66.43 \%$ & $-11,35 \%$ \\
\hline Frequent users & $43.96 \%$ & $58.69 \%$ & $-14,73 \%$ \\
\hline
\end{tabular}

Table 5. Users of Internet by gender. Source: AOSI (2008)

\subsection{Socioeconomic Aspects}

In this section, we review the relationship between gender use of ICTs and several socioeconomic aspects. We show that the percentage of women who use the Internet is higher than the percentage of men among the group of employees (as opposed to self-employed workers), almost ten points higher. In contrast, the proportion of male users is higher among self-employed workers and pensioners. Finally, there are not significant differences between male and female students.

\begin{tabular}{|l|l|l|l|}
\hline & Female & Male & Gap \\
\hline Self-employed & $70.47 \%$ & $77.50 \%$ & $-7.03 \%$ \\
\hline Employed as employee & $87.03 \%$ & $78.39 \%$ & $8.64 \%$ \\
\hline Student & $98.03 \%$ & $98.85 \%$ & $-0.82 \%$ \\
\hline Pensioner & $11.47 \%$ & $25.99 \%$ & $-14.52 \%$ \\
\hline
\end{tabular}

Table 6. Use of Internet by gender and occupation. Source: AOSI (2008)

According to many studies, education level is one of the major factors that influence technology access and usage.
Several studies underline that ICT-adoption behaviour is likely to be influenced by education (Borghans and Ter 
Weel, 2005). So, it is necessary to review the importance of education on the women technological adoption process.
Our data allow us to conclude that gender digital divide diminishes when the level of qualification increases. Table 6 shows this point.

\begin{tabular}{|l|l|l|l|}
\hline & Female & Male & \\
\hline Five-year degree & $93.50 \%$ & $92.32 \%$ & $1.18 \%$ \\
\hline Three-year degree & $93.13 \%$ & $96.59 \%$ & $-3.46 \%$ \\
\hline Secondary school & $80.61 \%$ & $77.56 \%$ & $3.05 \%$ \\
\hline Primary school & $24.99 \%$ & $42.14 \%$ & $-17.15 \%$ \\
\hline Without studies & $1.40 \%$ & $6.42 \%$ & $-5.02 \%$ \\
\hline
\end{tabular}

Table 7. Use of Internet by gender and education. Source: AOSI (2008)

\subsection{Activities and Uses of Internet}

Men and women have different interests in using the ICTs. If differences on the activities carried out by men and women on the Internet are analysed, some conclusions are obtained. As we can see in the following table, although general patterns are similar, men tend to use the Internet more frequently to read newspapers, listen to the radio, watch TV, to shop online, to play or to download games and to participate in discussions. Conversely, women use the Internet mainly for getting tickets for shows, getting touristic information, booking a holiday or chatting in a higher frequency than men.

\begin{tabular}{|l|l|l|l|}
\hline & Female & Male & \multicolumn{1}{|c|}{ Gap } \\
\hline Look up on a search engine & $93.69 \%$ & $92.02 \%$ & $1.67 \%$ \\
\hline Send and receive mails & $82.70 \%$ & $88.81 \%$ & $-6.11 \%$ \\
\hline Read newspapers, magazines, TV, radio & $64.41 \%$ & $74.47 \%$ & $-10.06 \%$ \\
\hline Touristic information and books & $58.24 \%$ & $50.20 \%$ & $8.04 \%$ \\
\hline Listen or download music & $49.62 \%$ & $48.38 \%$ & $1.24 \%$ \\
\hline P2P & $43.57 \%$ & $46.17 \%$ & $-2.60 \%$ \\
\hline Chat & $46.40 \%$ & $39.40 \%$ & $7.00 \%$ \\
\hline Information and tickets & $42.02 \%$ & $37.84 \%$ & $4.18 \%$ \\
\hline Bank operations & $31.90 \%$ & $32.02 \%$ & $-0.12 \%$ \\
\hline Online purchases & $27.78 \%$ & $34.68 \%$ & $-6.90 \%$ \\
\hline Play or download games & $17.73 \%$ & $29.14 \%$ & $-11.41 \%$ \\
\hline Participate in discussions and news groups & $12.66 \%$ & $24.30 \%$ & $-11.64 \%$ \\
\hline
\end{tabular}

Table 8. Use of Internet by gender and activities. Source: AOSI (2008)

Electronic commerce, namely, buying or selling products or services over electronic systems, have experimented a huge increase in the last years. However, there are differences in the patterns of use between men and women.

First of all, men are more used to getting information on the Internet to support their purchase decision. In our sample, $61.67 \%$ of men have used the Internet to this purpose, but only $45.26 \%$ of women have done it.

In addition, more than $15 \%$ of men have bought online recently, whereas this percentage represented less than $11 \%$ in the case of women in 2007.

Differences vary depending on the age of the buyers. As we can see in the next table, older women are the group 
where the digital divide is higher. Only $10.12 \%$ of women between 55 and 64 years shop on the Internet. It is in this age group where the gender digital divide reaches the highest level, $31.46 \%$. However, there is a cluster where the percentage of women shopping on the Internet is higher than that of men. It is the age group between 35 and 44.

To sum up, we can conclude that the gender digital divide is higher in the first and in the last part of women's labour life.

\begin{tabular}{|l|r|r|r|}
\hline & \multicolumn{1}{|c|}{ Female } & \multicolumn{1}{c|}{ Male } & \multicolumn{1}{l|}{ Gap } \\
\hline $15-24$ years & $31.62 \%$ & $43.55 \%$ & $-11.93 \%$ \\
\hline $25-34$ years & $39.20 \%$ & $51.67 \%$ & $-12.47 \%$ \\
\hline $35-44$ years & $40.68 \%$ & $39.32 \%$ & $1.36 \%$ \\
\hline $25-54$ years & $15.33 \%$ & $27.81 \%$ & $-12.48 \%$ \\
\hline $55-64$ years & $10.12 \%$ & $41.58 \%$ & $-31.46 \%$ \\
\hline
\end{tabular}

Table 9. Use of Internet by gender and age. Source: AOSI (2008)

\subsection{Barriers of Use}

According to the AOSI (2008) information, differences between genders are not significant when we ask non- users about the reason for not using ICTs. The next table shows the main barriers of Internet use:

\begin{tabular}{|c|c|c|c|}
\hline & Female & Male & Gap \\
\hline He/She doesn't need it & $55.92 \%$ & $65.87 \%$ & $-9.95 \%$ \\
\hline He/She doesn't know how to use the PC & $53.11 \%$ & $44.67 \%$ & $8.44 \%$ \\
\hline He/She doesn't know how to use the Internet & $47.41 \%$ & $38.48 \%$ & $8.93 \%$ \\
\hline He/She doesn't have a PC & $39.21 \%$ & $44.79 \%$ & $-5.58 \%$ \\
\hline He/She doesn't perceive Internet utility & $28.30 \%$ & $33.06 \%$ & $-4.76 \%$ \\
\hline He/She doesn't have time & $16.84 \%$ & $17.19 \%$ & $-0.35 \%$ \\
\hline He/She doesn't have broadband connection & $15.52 \%$ & $21.03 \%$ & $-5.51 \%$ \\
\hline He/She doesn't have anybody who can help him/her & $12.08 \%$ & $4.16 \%$ & $7.92 \%$ \\
\hline Difficulty of use perceived & $4.06 \%$ & $5.94 \%$ & $-1.88 \%$ \\
\hline It is very expensive & $3.99 \%$ & $2.79 \%$ & $1.20 \%$ \\
\hline Others & $48.20 \%$ & $37.53 \%$ & $10.67 \%$ \\
\hline
\end{tabular}

Table I0. Barriers of Internet use by gender. Source: Adapted from AOSI (2008)

In both cases, the lack of necessity is the main barrier to use Internet, followed by their ignorance about PCs and the Internet. We can highlight the absence of someone who helps women to improve their technological skills. $12.08 \%$ of women who don't use the Internet affirm that this is the difficulty they find. On the other hand, only $4.16 \%$ of men underline this problem.

\section{Conclusions}

In conclusion, we can sum up that the possibility of access to ICTs is, in general, similar to men and women. According to gender considerations, we show that women have more possibilities to access from home and men from the study or workplace. So, this is not one of the main 
causes of the gender digital divide. However we can find a digital divide between urban and rural women. The first ones have higher probabilities to get access to ICTs than the rural ones.

Moreover, differences exist on the intensity of use. Male frequency of use is quite higher than the intensity of female use, with a gap of $10 \%$ or more. Taking into account socioeconomic aspects, female use of ICTs is higher than male use among employees, but on the contrary, it is smaller among the self-employed group and pensioners, so we continue seeing a gender digital divide. This gap on the pensioners group is coherent with the gap showed on the 55-64 group, where the gender digital divide is the highest. It is according with those studies that conclude that men do not use ICT more than women, but simply sooner. It allows us to be confident that gender digital divide will decrease in the future, when the younger generations grow up. Moreover, the causes of these differences may be found also in other aspects, such us that women had lower incomes than men. So, it is necessary to resolve wage gap between men and women problems.

Finally, education seems to be also important. As we have seen, the gender digital divide diminishes when the level of qualification increases. However, it is difficult to establish a causality direction. Though there is a relationship between education level and ICTs use, it could be that access to education brings with it greater access to technology. In any case, a clear relationship is showed by our data for the Spanish region analized.

As conclusion, we can highlight that the current situation in the region analysed shows differences between men and women in several aspects, but gaps in ICTs use between genders are diminishing. So, it can be expected that women will close the gap and the percentage of women online will soon be nearly equal to that of men. It is especially important if we take into account that ICTs are a tool to challenge gender inequality and promote women's empowerment in many different ways. In any case, it is necessary to be aware of the potential gender divide and to continue expanding women's capacities through access and use of ICTs.

\section{Acknowledgements}

We would like to thank Universitary Fundation Antonio Gargallo and the CREVALOR Research Group (DGA-
Spain) for financial support and the Teruel Chamber of Commerce and Industry for providing us with data.

\section{References}

AOSI (2008). Penetración de Internet en Aragón. Evolución 2004-2007, Observatorio Aragonés de la Sociedad de la Información. Available at: http://www.observatorioaragones.org/estudios/Penetracion 2004-2007.pdf

BORGHANS, L., TER WEEL, B. (2005). How computerization has changed the labour market: $A$ review of the evidence and a new perspective.In L. Soete and B. ter Weel (eds.), The economics of the digital society, Edward Elgar: Cheltenham, 219-247, November 2005.

BUCY, E.P. (2000). Social Access to the Internet. Harvard International Journal of press/Politics, 5(I), 50-6I.

CASTAÑO, C. (2005). Las Mujeres y las Tecnologías de la Información. Internet y la Trama de Nuestra Vida. Alianza Editorial, Madrid.

DHOLAKIA, R.R. (2004/2005). Gender and Internet Use: Peeking Under the Covers. William A. Orme Working Paper Series, 2004/2005 No. 6. Available at: http://www.cba.uri.edu/offices/research/workingpapers/doc uments/GenderAndInternetUsePeekingUnderTheCovers.p df

DHOLAKIA, R.R., KSHETRI, N. (2002). Gender asymmetry in the adoption of internet and e-commerce. Center for Research on Information Technology and Organizations (CRITO). Available at: http://www.crito.uci.edu/noah/HOIT/HOIT\%20Papers/Gen der\%20Asymmetry.pdf

FINK, C., KENNY, C.J. (2003). W(h)lther the Digital Divide?. Development Gateway, 2003.

KORUPP, S., SZYDLIK, M. (2005). Causes and Trends of the Digital Divide. European Sociological Review, 2 I (4), 40922.

KOVAČIĆ, Z.J., VUKMIROVIĆ, D. (2008). ICT Adoption and the Digital Divide in Serbia: Factors and Policy Implications. Proceedings of the Informing Science \& IT Education Conference (InSITE), available at: 
http://proceedings.informingscience.org/InSITE2008/InSITE

08p363-387Kova540.pdf

MERI, T. (2008). Human Resources employed in Science

and Technology Occupations Professionals and Technicians. Eurostat. Statistics in focus 77/2008. Available at:

http://epp.eurostat.ec.europa.eu/cache/ITY OFFPUB/KSSF-08-077/EN/KS-SF-08-077-EN.PDF

OECD (2007). ICTs and Gender. Working Party on the Information Economy, Directorate for Science, Technology and Industry. Committee for Information, Computer and Communication Policy.

RABAN, Y. (2004). e-Living DII.I - ICT Uptake and Usage: Panel Data Analysis. The e-Living Consortium, IST. Available at: http://www.eurescom.de/e-living

UNDP / UNIFEM (2004). Bridging the Gender Digital Divide. ISBN 92-95042-06-9. Available at: http://web.undp.sk/uploads/Gender\%20and\%20ICT\%20reg rep eng.pdf 